\title{
Radiation Sterilization of Anthracycline Antibiotics in Solid State
}

\author{
A. Kaczmarek, ${ }^{1}$ J. Cielecka-Piontek, ${ }^{2}$ P. Garbacki, ${ }^{2}$ K. Lewandowska, ${ }^{3}$ W. Bednarski, ${ }^{3}$ \\ B. Barszcz, ${ }^{3}$ P. Zalewski, ${ }^{2}$ W. Kycler, ${ }^{4}$ I. Oszczapowicz, ${ }^{5}$ and A. Jelińska ${ }^{2}$ \\ ${ }^{1}$ Biofarm Sp. z o.o., Wałbrzyska 13, 60-198 Poznań, Poland \\ ${ }^{2}$ Department of Pharmaceutical Chemistry, Faculty of Pharmacy, Poznan University of Medical Sciences, Grunwaldzka 6, \\ 60-780 Poznań, Poland \\ ${ }^{3}$ Institute of Molecular Physics, Polish Academy of Sciences, Smoluchowskiego 17, 60-179 Poznań, Poland \\ ${ }^{4}$ Department of Oncological Surgery II, Great Poland Cancer Centre, Garbary 15, 61-866 Poznań, Poland \\ ${ }^{5}$ Department of Modified Antibiotics, Institute of Biotechnology and Antibiotics, Starościnska 5, 02-516 Warsaw, Poland
}

Correspondence should be addressed to P. Garbacki; pgarbacki@ump.edu.pl

Received 23 August 2013; Accepted 19 September 2013

Academic Editors: J. McHowat and S. J. Rajput

Copyright (C) 2013 A. Kaczmarek et al. This is an open access article distributed under the Creative Commons Attribution License, which permits unrestricted use, distribution, and reproduction in any medium, provided the original work is properly cited.

\begin{abstract}
The impact of ionizing radiation generated by a beam of electrons of $25-400 \mathrm{kGy}$ on the stability of such analogs of anthracycline antibiotics as daunorubicin (DAU), doxorubicin (DOX), and epidoxorubicin (EPI) was studied. Based on EPR results, it was established that unstable free radicals decay exponentially with the half-time of 4 days in DAU and DOX and 7 days in EPI after irradiation. Radiation-induced structural changes were analyzed with the use of spectrophotometric methods (UV-Vis and IR) and electron microscope imaging (SEM). A chromatographic method (HPLC-DAD) was applied to assess changes in the contents of the analogs in the presence of their impurities. The study showed that the structures of the analogs did not demonstrate any significant alterations at the end of the period necessary for the elimination of unstable free radicals. The separation of main substances and related substances (impurities and potential degradation products) allowed determining that no statistically significant changes in the content of particular active substances occurred and that their conversion due to the presence of free radicals resulting from exposure to an irradiation of $25 \mathrm{kGy}$ (prescribed to ensure sterility) was not observed.
\end{abstract}

\section{Introduction}

Anthracycline antibiotics belong to the group of anticancer drugs. They were originally isolated from cultures of Streptomyces. Anthracyclines are widely used in the treatment of neoplastic diseases such as leukemia, breast cancer, and AIDS-related Kaposi's sarcoma. They also demonstrate activity against tumors of the ovaries, lung, testes, prostate, cervix, bladder, and Ewing's sarcoma [1-3]. The most widely used anthracyclines are doxorubicin (DOX), daunorubicin (DAU), and epidoxorubicin (EPI) [4-6] (Figure 1). Their low bioavailability necessitates parenteral administration $[7,8]$, which requires sterility [9] obtained mainly by filtration. Given the considerable exposure of medical personnel to anthracycline antibiotics and their adsorption to most surfaces, especially those of sterilization filters, there is a need to find new sterilization methods that do not rely on filtration. Although radiation sterilization is an effective alternative, the structure of drugs may alter as a consequence of exposure to irradiation. The aglycone attached to the aminosugar with a glycoside bond may be prone to cleavage resulting from electron transfer within the molecule. Stability studies demonstrated degradation of anthracycline antibiotics in solutions, under the influence of increased temperature and when exposed to light in the solid state as well as a consequence of combining chemotherapy with radiotherapy [10-15]. Regarding the effects of radiation sterilization on anthracycline antibiotics, only DOX was studied in that respect with a focus on the impact of a standard dose of $25 \mathrm{kGy}$ on its stability [16]. As DAU and EPI are widely used in anticancer pharmacotherapy, those antibiotics also require analysis of their vulnerability to ionizing radiation. 
<smiles>COc1cccc2c1C(=O)c1c(O)c3c(c(O)c1C2=O)C[C@@](O)(C(C)=O)C[C@@H]3O[C@H]1C[C@@H](N)[C@H](O)[C@H](C)O1</smiles>

Daunorubicin

(a)<smiles>COc1cccc2c1C(=O)c1c(O)c3c(c(O)c1C2=O)C[C@@](O)(C(=O)CO)C[C@@H]3O[C@H]1C[C@@H](N)[C@H](O)[C@H](C)O1</smiles>

Doxorubicin

(b)<smiles>COc1cccc2c1C(=O)c1c(O)c3c(c(O)c1C2=O)C[C@@](O)(C(=O)CO)C[C@@H]3O[C@H]1C[C@@H](N)[C@H](C)C(C)O1</smiles>

Epidoxorubicin

(c)

Figure 1: Chemical structures of daunorubicin, doxorubicin, and epidoxorubicin.

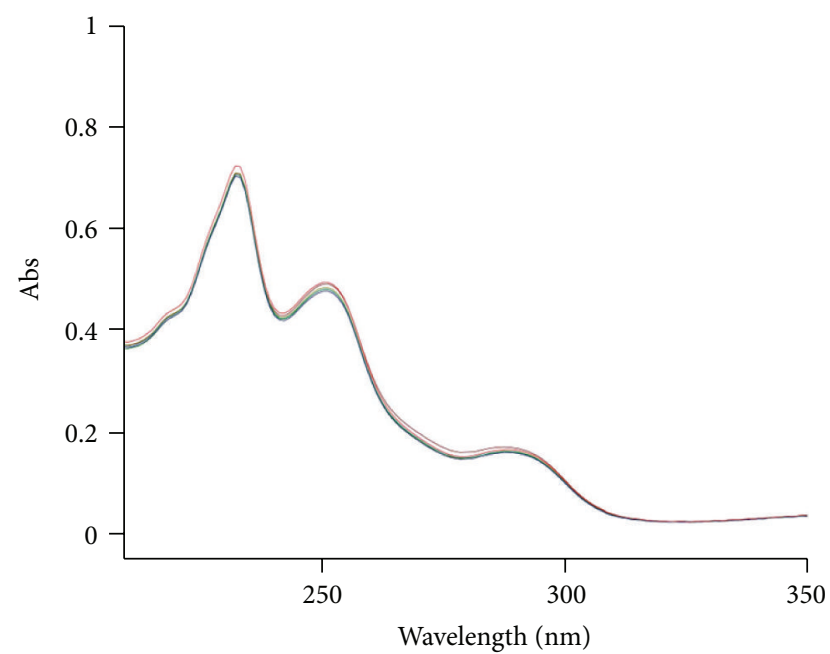

FIGURE 2: UV spectra of unirradiated and gamma irradiated daunorubicin.

The aim of this work was to assess the possibility of applying radiation sterilization to DOX, DAU, and EPI as active substances or conversion-induced impurities.

\section{Materials and Methods}

2.1. Samples. DOX, DAU, and EPI were synthesized at the Institute of Biotechnology and Antibiotics, Department of

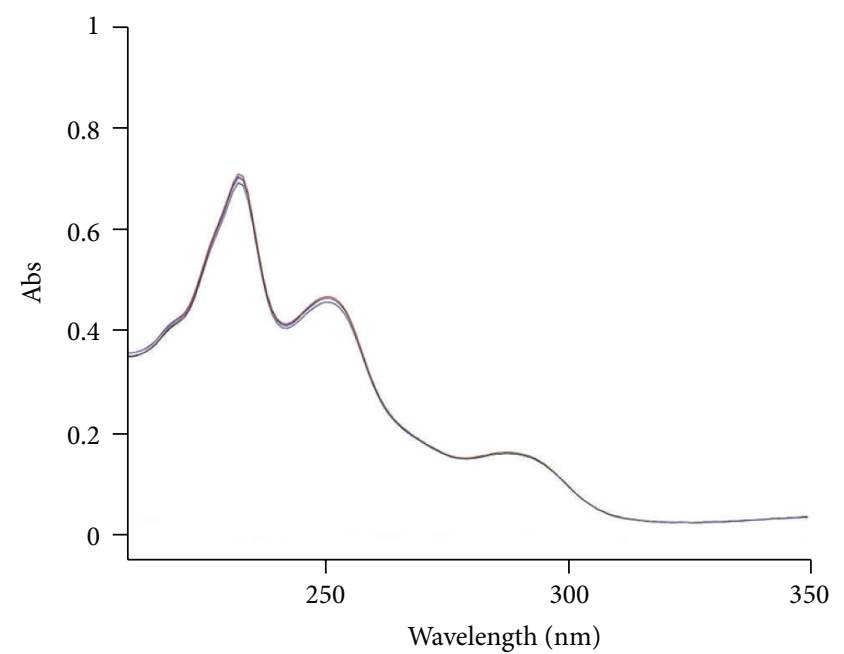

FIGURE 3: UV spectra of unirradiated and gamma irradiated doxorubicin.

Modified Antibiotics, Warsaw, Poland. They were reddish powders, freely soluble in water and methanol. Sodium lauryl sulfate, phosphoric acid, and all other chemicals were obtained from Merck KGaA (Germany) and were of analytical or high-performance liquid chromatographic grade.

2.2. Irradiation. $0.025 \mathrm{~g}$ samples of each substance were placed in $3 \mathrm{~mL}$ colorless glass vials that were closed with 
TABLE 1: Main characteristic vibrational modes of daunorubicin (DAU), doxorubicin (DOX), and epidoxorubicin (EPI) observed in experimental and calculated spectra.

\begin{tabular}{|c|c|c|c|c|c|c|}
\hline \multicolumn{3}{|c|}{ Calculation $\left(\mathrm{cm}^{-1}\right)$} & \multicolumn{3}{|c|}{ Experimental $\left(\mathrm{cm}^{-1}\right)$} & \multirow{2}{*}{ Band assignment } \\
\hline DAU & DOX & EPI & DAU & DOX & EPI & \\
\hline 723 & 736 & 736 & 764 & 761 & 761 & $\begin{array}{l}\mathrm{C}-\mathrm{C}-\mathrm{C} b \text { in a ring }+ \text { def. aglycone group }+ \text { breathing } \\
\text { tetrahydropyran ring in aminosugar group }+\mathrm{NH}_{2} w\end{array}$ \\
\hline 752 & 754 & 749 & 795 & 795 & 795 & $\begin{array}{l}\mathrm{NH}_{2} w+\mathrm{C}-\mathrm{C}-\mathrm{C} b \text { in aminosugar group }+\mathrm{C}-\mathrm{H} w \text { at } \mathbf{d} \\
\text { ring and in aminosugar group }\end{array}$ \\
\hline 776 & 773 & 774 & 816 & 804 & 805 & $\begin{array}{l}\mathrm{C}-\mathrm{C}-\mathrm{C} b \text { in a ring }+ \text { def. aglycone group }+ \text { breathing } \\
\text { tetrahydropyran ring in aminosugar group }+\mathrm{CH}_{2} r \text { at } \mathbf{d} \\
\text { ring }\end{array}$ \\
\hline 931 & 930 & 935 & 940 & 939 & 939 & $\mathrm{C}-\mathrm{O}-\mathrm{H} b$ at $\mathrm{c}$ ring $+\mathrm{C}-\mathrm{H} w$ in aminosugar group \\
\hline 959 & 957 & 951 & 955 & 949 & 949 & $\begin{array}{l}\mathrm{C}-\mathrm{C}-\mathrm{C} b \text { in } \mathbf{d} \text { ring }+\mathrm{NH}_{2} w+\mathrm{CH} w \text { at } \mathbf{d} \text { ring and } \\
\text { aminosugar group }\end{array}$ \\
\hline 984 & - & - & & & & $\mathrm{CH}_{3} w$ in $\mathrm{COCH}_{3}$ group \\
\hline 1010 & 1008 & 1006 & 986 & 990 & 989 & $\begin{array}{l}\text { Breathing aglycone group }+\mathrm{CH}_{2} r+\mathrm{NH}_{2} r+\mathrm{CH}_{3} w \text { in } \\
\mathrm{COCH}_{3}+\mathrm{CH}_{2} w \text { in } \mathrm{COCH}_{2} \mathrm{OH}\end{array}$ \\
\hline 1021 & 1029 & 1032 & 1008 & 1005 & 1005 & $\begin{array}{l}\text { Breathing a ring + def. aglycone group }+\mathrm{C}-\mathrm{O} s \text { at a ring } \\
+\mathrm{C}-\mathrm{O}-\mathrm{H} b \text { at } \mathbf{c} \text { ring }+\mathrm{NH}_{2} w+\mathrm{CH}_{3} w \text { in } \mathrm{COCH}_{3} \\
\text { group }\end{array}$ \\
\hline 1079 & 1078 & 1065 & 1070 & 1072 & 1072 & $\begin{array}{l}\mathrm{C}-\mathrm{O} s \text { between tetrahydropyran ring and } \mathrm{O}-\mathrm{H} \text { group in } \\
\text { aminosugar group }\end{array}$ \\
\hline 1105 & 1104 & 1104 & 1085 & 1089 & 1089 & $\begin{array}{l}\mathrm{C}-\mathrm{O} s \text { in metoxy group at a ring }+\mathrm{C}-\mathrm{C}-\mathrm{C} b \text { in a ring }+ \\
\mathrm{CH}_{2} r\end{array}$ \\
\hline 1123 & 1123 & 1122 & 1109 & 1114 & 1114 & $\begin{array}{l}\mathrm{C}-\mathrm{O} s \text { in tetrahydropyran ring }+\mathrm{C}-\mathrm{O} s \text { in glycosidic } \\
\text { bond }+\mathrm{C}-\mathrm{C} s \text { in } \mathbf{d} \text { ring }+\mathrm{C}-\mathrm{H} w \text { in } \mathrm{CH}_{3} \text { in aminosugar } \\
\text { group }\end{array}$ \\
\hline 1137 & 1139 & 1136 & 1109 & 1114 & 1114 & $\begin{array}{l}\mathrm{C}-\mathrm{C} s \text { in } \mathbf{d} \text { ring and in tetrahydropyran ring in } \\
\text { aminosugar group }+\mathrm{C}-\mathrm{H} b \text { at } \mathbf{d} \text { ring and in } \\
\text { tetrahydropyran ring in aminosugar group }+\mathrm{CH}_{3} w \text { in } \\
\mathrm{COCH}_{3} \text { group }+\mathrm{C}-\mathrm{O} s \text { in } \mathrm{COCH}_{2} \mathrm{OH} \text { group }\end{array}$ \\
\hline 1157 & 1157 & 1156 & 1153 & 1143 & 1143 & $\begin{array}{l}\mathrm{C}-\mathrm{O} s \text { in glycosidic bond }+\mathrm{C}-\mathrm{O} s \text { between } \\
\text { tetrahydropyran ring and } \mathrm{O}-\mathrm{H} \text { group in aminosugar } \\
\text { group }+\mathrm{C}-\mathrm{H} r \text { in } \mathrm{CH}_{3} \text { in aminosugar group }+ \text { def. } \mathbf{d} \\
\text { ring }\end{array}$ \\
\hline 1206 & 1205 & 1200 & 1194 & 1201 & 1201 & $\begin{array}{l}\mathrm{C}-\mathrm{O} s \text { in glycosidic bond }+\mathrm{C}-\mathrm{C} s \mathrm{I} \mathrm{d} \text { ring }+\mathrm{C}-\mathrm{H} b \text { at } \mathbf{d} \\
\text { ring and aminosugar group }\end{array}$ \\
\hline 1226 & 1225 & 1221 & 1205 & 1211 & 1211 & $\mathrm{CH}_{2} t$ at $\mathbf{d}$ ring + breathing a ring $+\mathrm{C}-\mathrm{O}-\mathrm{H} b$ at $\mathbf{c}$ ring \\
\hline- & 1239 & 1239 & & 1235 & 1235 & $\mathrm{C}-\mathrm{O}-\mathrm{H} b$ in $\mathrm{COCH}_{2} \mathrm{OH}$ group \\
\hline 1278 & 1275 & 1275 & 1262 & 1263 & 1263 & $\begin{array}{l}\mathrm{C}-\mathrm{O}-\mathrm{H} b \text { at } \mathrm{c} \text { ring }+\mathrm{C}-\mathrm{C} s \text { in aglycone group }+\mathrm{CH}_{2} t \\
\text { in } \mathrm{COCH}_{2} \mathrm{OH} \text { group }\end{array}$ \\
\hline 1291 & 1290 & 1293 & 1289 & 1284 & 1285 & $\mathrm{C}-\mathrm{O}-\mathrm{H} b$ at $\mathbf{c}$ ring + breathing $\mathbf{a}$ and $\mathbf{c}$ ring \\
\hline 1317 & 1317 & 1318 & 1289 & 1284 & 1285 & $\begin{array}{l}\text { Breathing } \mathrm{c} \text { ring }+\mathrm{C}-\mathrm{O} s \text { at } \mathbf{c} \text { ring }+\mathrm{C}-\mathrm{O} s \text { at a ring }+ \\
\mathrm{CH}_{2} w \text { at a ring }+\mathrm{C}-\mathrm{H} w \text { at } \mathbf{d} \text { ring }\end{array}$ \\
\hline 1329 & 1329 & 1330 & 1317 & 1318 & 1318 & $\mathrm{C}-\mathrm{O} s$ at a ring + breathing $\mathbf{a}$ and $\mathbf{c}$ ring \\
\hline 1367 & 1367 & 1366 & 1374 & 1374 & 1374 & $\begin{array}{l}\mathrm{C}-\mathrm{C}-\mathrm{C} b \text { in } \mathbf{d} \text { ring }+\mathrm{C}-\mathrm{C} s \text { in } \mathbf{a} \text { and } \mathbf{b} \text { ring }+\mathrm{C}-\mathrm{O} s \text { at } \mathbf{c} \\
\text { ring }+\mathrm{C}-\mathrm{O}-b \text { at } \mathbf{c} \text { ring }\end{array}$ \\
\hline 1404 & - & - & & & & $\mathrm{CH}_{3}$ sc in $\mathrm{COCH}_{3}$ group \\
\hline 1425 & 1427 & 1423 & 1404 & 1413 & 1413 & $\mathrm{O}-\mathrm{C}-\mathrm{H} b+\mathrm{N}-\mathrm{C}-\mathrm{H} b$ \\
\hline 1476 & 1476 & 1478 & 1474 & 1471 & 1472 & $\begin{array}{l}\mathrm{C}-\mathrm{O} s \text { at } \mathrm{c} \text { ring }+ \text { def. } \mathrm{c} \text { ring }+\mathrm{CH}_{3} \text { umbrella mode at a } \\
\text { ring }+\mathrm{C}-\mathrm{O}-\mathrm{H} b \text { at } \mathbf{c} \text { ring }\end{array}$ \\
\hline
\end{tabular}


TABle 1: Continued.

\begin{tabular}{|c|c|c|c|c|c|c|}
\hline \multicolumn{3}{|c|}{ Calculation $\left(\mathrm{cm}^{-1}\right)$} & \multicolumn{3}{|c|}{ Experimental $\left(\mathrm{cm}^{-1}\right)$} & \multirow{2}{*}{ Band assignment } \\
\hline DAU & DOX & EPI & DAU & DOX & EPI & \\
\hline 1502 & 1502 & 1505 & 1506 & 1507 & 1507 & $\begin{array}{l}\mathrm{C}-\mathrm{O}-\mathrm{H} b \text { at } \mathrm{c} \text { ring }+\mathrm{CH}_{3} \mathrm{sc} \text { at a ring }+\mathrm{C}-\mathrm{C} s \text { in } \\
\text { aglycone group }\end{array}$ \\
\hline 1524 & 1524 & 1527 & & 1525 & 1524 & $\begin{array}{l}\mathrm{C}-\mathrm{O}-\mathrm{H} b \text { at } \mathrm{c} \text { ring }+\mathrm{CH}_{3} \mathrm{sc} \text { at a ring }+\mathrm{C}-\mathrm{C} s \text { in } \\
\text { aglycone group }\end{array}$ \\
\hline 1614 & 1615 & 1615 & 1576 & 1582 & 1581 & $\begin{array}{l}\mathrm{C}-\mathrm{C} s \text { in } \mathbf{c} \text { ring }+\mathrm{C}-\mathrm{O}-\mathrm{H} b \text { at } \mathbf{c} \text { ring }+\mathrm{C}=\mathrm{O} s \text { at } \mathbf{b} \text { ring }+ \\
\mathrm{C}-\mathrm{C} s \text { in a ring }\end{array}$ \\
\hline 1640 & 1640 & 1642 & 1576 & 1582 & 1581 & $\mathrm{C}-\mathrm{C} s$ in a ring $+\mathrm{C}-\mathrm{O}-\mathrm{H} b$ at $\mathbf{c}$ ring $+\mathrm{CH}_{3} w$ at a ring \\
\hline 1661 & 1663 & 1663 & 1617 & 1616 & 1616 & $\mathrm{NH}_{2} \mathrm{sc}$ \\
\hline 1688 & 1688 & 1688 & 1617 & 1616 & 1616 & $\mathrm{C}=\mathrm{O} s$ at $\mathbf{b}$ ring $+\mathrm{C}-\mathrm{O}-\mathrm{H} b$ at $\mathbf{c}$ ring \\
\hline 1744 & 1744 & 1745 & 1707 & 1717 & 1717 & $\mathrm{C}=\mathrm{O} s$ at $\mathbf{b}$ ring \\
\hline 1791 & 1808 & 1807 & 1716 & 1730 & 1730 & $\mathrm{C}=\mathrm{O} s$ at $\mathbf{d}$ ring \\
\hline $2967-3237$ & & & $2844-3108$ & & & $\mathrm{C}-\mathrm{H} s$ \\
\hline 3009 & 3010 & 2960 & 2878 & 2896 & 2896 & $\mathrm{O}-\mathrm{H} s$ at $\mathbf{c}$ ring \\
\hline 3488 & 3488 & 3485 & & & & $\mathrm{~N}-\mathrm{H} s$ symmetric \\
\hline 3566 & 3566 & 3571 & & & & $\mathrm{~N}-\mathrm{H} s$ antisymmetric \\
\hline 3630 & 3634 & 3639 & 3161 & 3326 & 3329 & $\mathrm{O}-\mathrm{H} s$ \\
\hline 3791 & 3788 & 3785 & & 3527 & 3527 & $\mathrm{O}-\mathrm{H} s$ \\
\hline 3809 & 3801 & - & & & & $\mathrm{O}-\mathrm{H} s$ \\
\hline- & 3831 & 3831 & & 3545 & 3545 & $\mathrm{O}-\mathrm{H} s$ in $\mathrm{COCH}_{2} \mathrm{OH}$ group \\
\hline
\end{tabular}

Vibrational modes $-s$ : stretching, $b$ : bending, $w$ : wagging, $s c$ : scissoring, $r$ : rocking, and $t$ : twisting.

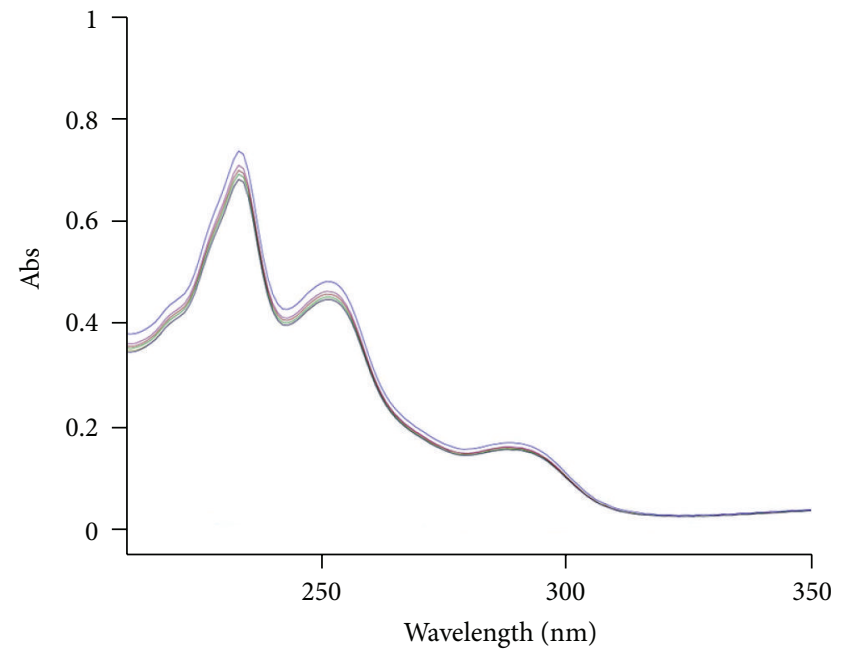

FIGURE 4: UV spectra of unirradiated and gamma irradiated epidoxorubicin.

plastic stoppers. The samples in the vials were exposed to beta irradiation in a linear electron accelerator LAE 13/9 (9.96 MeV electron beam and $6.2 \mu \mathrm{A}$ current intensity) until they absorbed doses of 25, 50, 100, 200, and $400 \mathrm{kGy}$.

\subsection{Electron Paramagnetic Resonance (EPR) Spectroscopy.} Detection of free radicals and determination of their concentration were carried out using a Bruker ELEXSYS 500 spectrometer (X-band) at $297 \mathrm{~K}$. EPR spectra were recorded

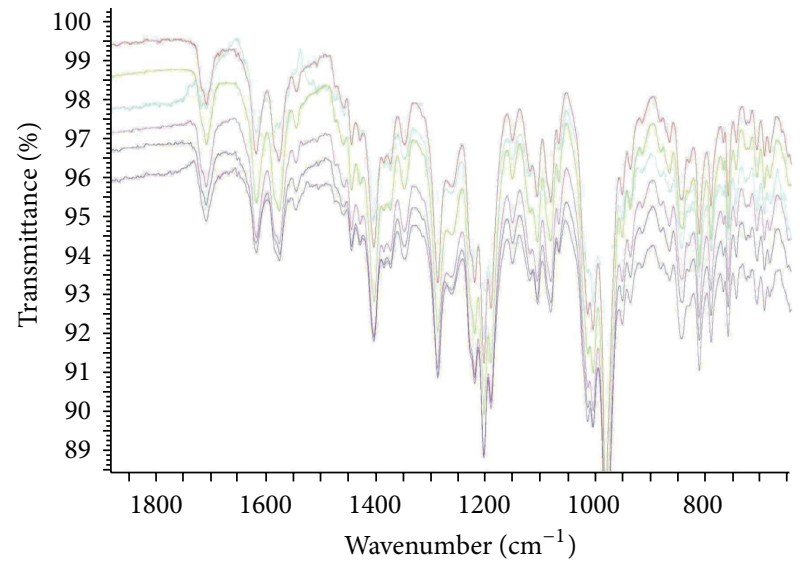

FIGURE 5: FT-IR spectra of unirradiated and gamma irradiated daunorubicin.

as a first derivative of the absorption signal. The number of free radicals was calculated using the integration procedure described elsewhere [17].

2.4. UV-Vis Spectroscopy. Chemical changes in nonirradiated and irradiated samples were analyzed by using a UV-Vis Varian Carry 100 spectrophotometer. $2 \mathrm{mg}$ of each sample was dissolved in $20.0 \mathrm{~mL}$ of methanol. $1.0 \mathrm{~mL}$ of the so-obtained solution was diluted to $10.0 \mathrm{~mL}$ with methanol. The final concentration of the solutions was $0.01 \mathrm{mg} / \mathrm{mL}$. Absorption 


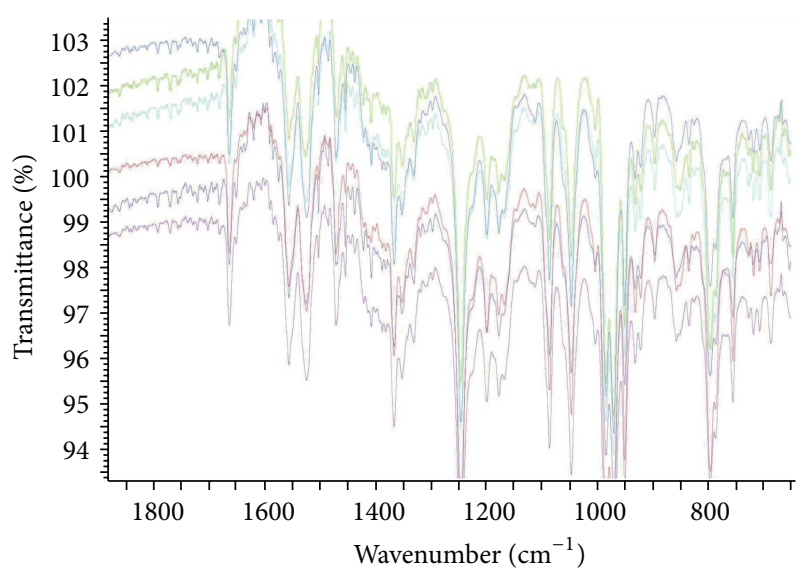

FIGURE 6: FT-IR spectra of unirradiated and gamma irradiated doxorubicin.

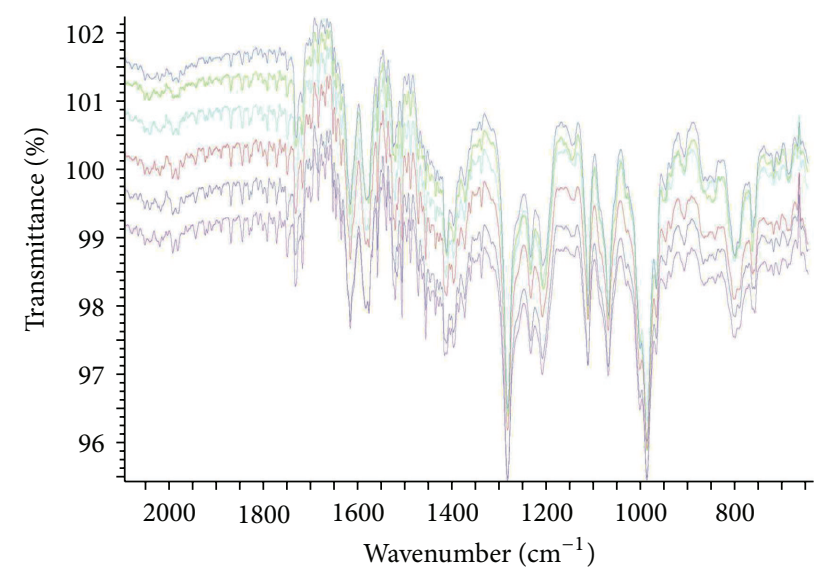

FIGURE 7: FT-IR spectra of unirradiated and gamma irradiated epidoxorubicin.

spectra of the so-prepared solutions were recorded in the wavelength range $190-900 \mathrm{~nm}$.

2.5. IR Spectroscopy. IR spectra of nonirradiated and irradiated anthracyclines were taken with the use of a Thermo Scientific Nicolet iS10 spectrophotometer with the Omnic software. The infrared transmittance spectra of the crystalline samples were recorded after a time necessary to achieve plateaus in EPR study, in the frequency range from 400 to $7500 \mathrm{~cm}^{-1}$, at room temperature.

2.6. HPLC Analysis. An HPLC Waters Alliance e2695 system was used for chromatographic separation of the degradation products of nonirradiated and irradiated DOX, DAU and EPI samples. All the samples $(1 \mathrm{mg} / \mathrm{mL})$ were dissolved in the mobile phase. A Symmetry C18 $(250 \times 4.6 \mathrm{~mm}, 5 \mu \mathrm{m})$ analytical column was employed as a stationary phase. The mobile phase consisted of solution A (acetonitrile) and solution B (2.88 g of sodium lauryl sulfate and $2.25 \mathrm{~g}$ of phosphoric $\operatorname{acid}(V) 85 \%$ in $1000 \mathrm{~mL})(50: 50, \mathrm{v}: \mathrm{v})$. UV detection was

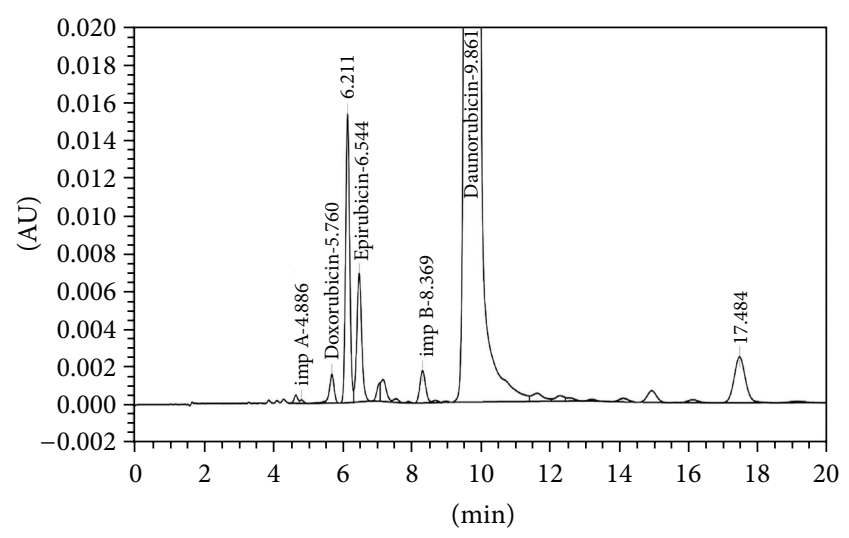

FIGURE 8: HPLC profile of unirradiated daunorubicin.

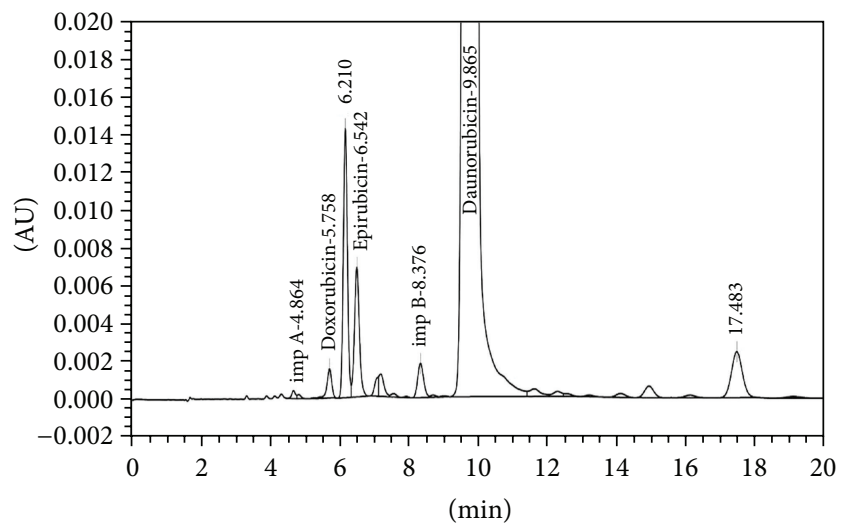

FIGURE 9: HPLC profile of irradiated daunorubicin (25 kGy).

performed at $254 \mathrm{~nm}$. The flow rate was $1.0 \mathrm{~mL} / \mathrm{min}$. The injected volume was $5 \mu \mathrm{L}$.

2.7. Theoretical Analysis. All the calculations were made by using the Gaussian 03 package [18]. In order to interpret the experimental results of IR absorption scattering, quantum chemical calculations were performed based on a density functional theory (DFT) method with the B3LYP hybrid functional and 6-31G(d,p) basis set.

\section{Results and Discussions}

The first EPR analysis was performed 1 day after irradiation for samples exposed to a dose of $25 \mathrm{kGy}$. DOX, DAU, and EPI irradiated at $25 \mathrm{kGy}$ contained about $3.94 \times 10^{15} \mathrm{spins} / \mathrm{g}$, $1.37 \times 10^{15} \mathrm{spins} / \mathrm{g}$, and $2.44 \times 10^{15} \mathrm{spins} / \mathrm{g}$, respectively. Exponential decay of unstable free radical was observed with the half-time of 4 days in DAU and DOX and 7 days in EPI after irradiation. The EPR signals of the sterilized anthracycline antibiotics were very weak. The plateaus of free radical concentrations versus time for DOX and DAU appeared after about 10 days, whereas for EPI after 20 days. EPR spectra after these periods consisted approximately of only stable free radicals. 


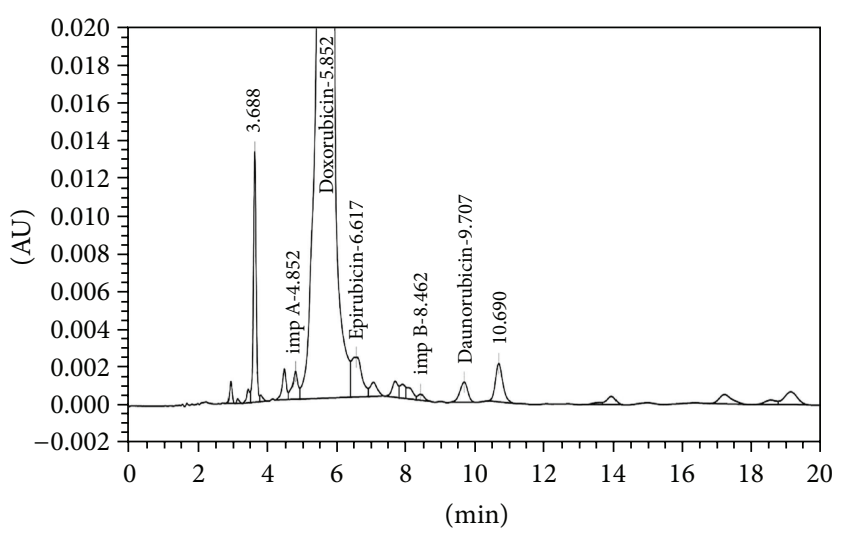

FIGURE 10: HPLC profile of unirradiated doxorubicin.

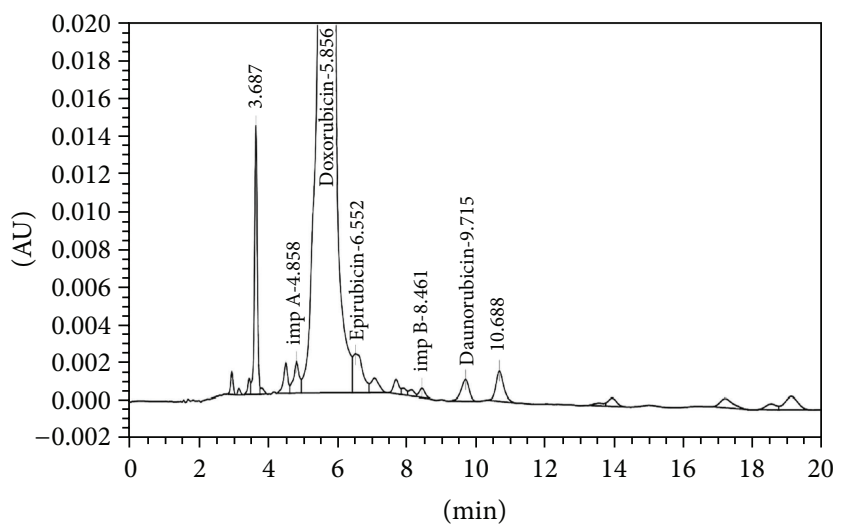

FIGURE 11: HPLC profile of irradiated doxorubicin (25 kGy).

The analytical study was conducted during a period when only stable free radicals were detected by EPR. The impact of an irradiation dose size on the structure of DAU, DOX, and EPI was studied at 0, 25, 50, 100, 200, and $400 \mathrm{kGy}$ without the presence of unstable free radical in EPR spectra. By using UV-Vis spectroscopy the location and the intensity of the absorption maximum were determined, whereas IR spectroscopy was employed to establish the intensity, location, and type of characteristic vibrations. For the DAU, DOX, and EPI samples no significant changes in the location $(\sim 289 \mathrm{~nm}, \sim 233 \mathrm{~nm}$, and $221 \mathrm{~nm})$ or intensity of the absorption maximum were recorded (Figures 2, 3, and 4). The spectra of their nonirradiated and irradiated samples did not show any essential differences in the value of absorbance. All samples exhibited two absorption maxima, at $233 \mathrm{~nm}$ and $251 \mathrm{~nm}$. The IR spectra of DOX, DAU, and EPI were compared with the theoretical spectra based on the density functional theory. The main characteristic vibrations obtained from the IR spectra are collected in Table 1. The conformation between the calculated and experimental spectra is quite good. The most significant is the region between 700 and $1800 \mathrm{~cm}^{-1}$, where intense and characteristic bands related to intramolecular vibrations of the molecules are observed, including the deformation of rings as well as stretching of various $\mathrm{C}-\mathrm{C}$ bonds (Figures 5, 6, and 7). Vibrational spectra

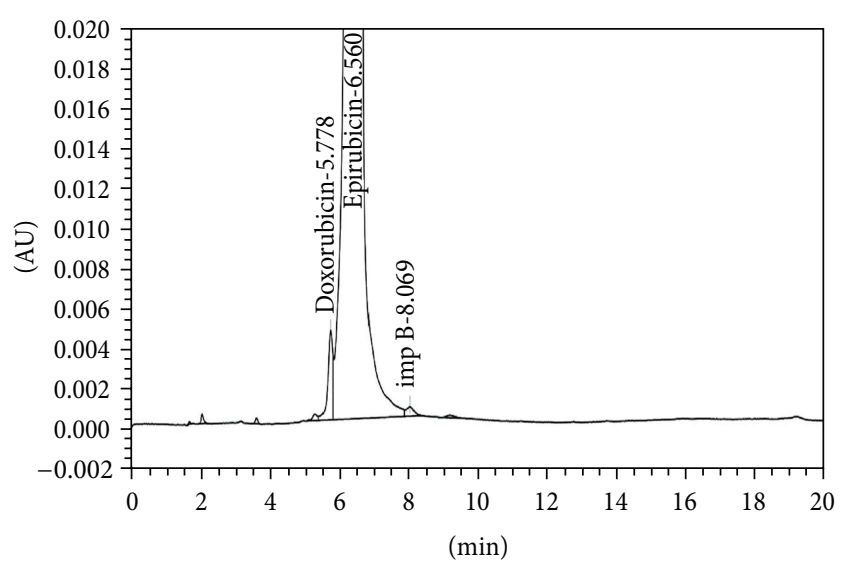

FIGURE 12: HPLC profile of unirradiated epidoxorubicin.

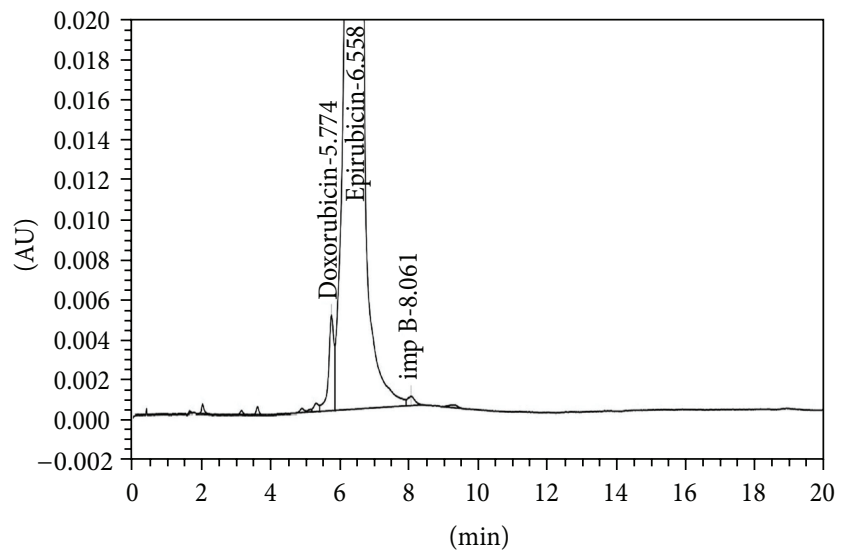

FIgURE 13: HPLC profile of irradiated epidoxorubicin (25kGy).

of the nonirradiated and irradiated samples of the three samples are very similar. We did not observe any change in the position and shape of the bands. This suggests that the radiation sterilization does not influence the stability of the DOX, DAU, and EPI. Similar results were received by comparing SEM images of the nonirradiated and irradiated samples. Taking into account the biological activity of the most important impurities specified by Ph. Eur. [9], changes in the concentration of the main substances in the presence of those impurities were analyzed (Figures $8,9,10,11,12$, and 13). By separating the compounds to be examined from the impurities, it was possible to assess changes in their content before and after irradiation at $25 \mathrm{kGy}$. It was found that exposure to such a dose of radiation did not produce any changes in the concentrations of the main substances or the impurities. Slight alterations were registered when the samples of DAU, DOX, and EPI were exposed to greater doses of radiation. Under such conditions, EPI demonstrated the greatest content change, and the presence of unstable free radicals was noted for the longest period of time. It was also proved, by observing the mass balance, that the main substances did not convert into unknown impurities. Similar studies of some tetracycline analogs showed that the 
aglycon was stable when irradiated at $25 \mathrm{kGy}$ and that changes occurred when greater radiation doses were applied [19]. It may therefore be proposed that not only a modification of the aglycon structure but also its ability to bind with a sugar moiety of specific stereoisomerism are the factors that stabilize the structures of analogs of anthracycline antibiotics.

\section{Conclusions}

The current study of the impact of radiation sterilization on the stability of DAU, DOX, and EPI demonstrates that this kind of sterilization may be an alternative to filtration recommended for sterilizing analogs of anthracycline antibiotics. The effect of radiation sterilization on the stability of DAU, DOX, and EPI depends on the structure of a particular compound. With regard to those analogs, it is important to assay the postirradiation content of the main substance in the presence of all possible related substances in order to determine whether other degradation products or postirradiation conversion occur.

\section{References}

[1] G. N. Hortobágyi, "Anthracyclines in the treatment of cancer: an overview," Drugs, vol. 54, no. 4, pp. 1-7, 1997.

[2] G. Minotti, P. Menna, E. Salvatorelli, G. Cairo, and L. Gianni, "Anthracyclines: molecular advances and pharmacologie developments in antitumor activity and cardiotoxicity," Pharmacological Reviews, vol. 56, no. 2, pp. 185-229, 2004.

[3] R. B. Weiss, "The anthracyclines: will we ever find a better doxorubicin?" Seminars in Oncology, vol. 19, no. 6, pp. 670-686, 1992.

[4] H. Cortés-Funes and C. Coronado, "Role of anthracyclines in the era of targeted therapy," Cardiovascular Toxicology, vol. 7, no. 2, pp. 56-60, 2007.

[5] O. Pagani, C. Sessa, G. Martinelli et al., "Dose-finding study of epidoxorubicin and docetaxel as first-line chemotherapy in patients with advanced breast cancer," Annals of Oncology, vol. 10, no. 5, pp. 539-545, 1999.

[6] A. Romanini, L. Tanganelli, F. Carnino et al., "First-line chemotherapy with epidoxorubicin, paclitaxel, and carboplatin for the treatment of advanced epithelial ovarian cancer patients," Gynecologic Oncology, vol. 89, no. 3, pp. 354-359, 2003.

[7] E. Wang, K. Lew, M. Barecki, C. N. Casciano, R. P. Clement, and W. W. Johnson, "Quantitative distinctions of active site molecular recognition by P-glycoprotein and cytochrome $\mathrm{P} 450$ 3A4," Chemical Research in Toxicology, vol. 14, no. 12, pp. 15961603, 2001.

[8] M. Fakhoury, C. Litalien, Y. Medard et al., "Localization and mRNA expression of CYP3A and P-glycoprotein in human duodenum as a function of age," Drug Metabolism and Disposition, vol. 33, no. 11, pp. 1603-1607, 2005.

[9] European Pharmacopoeia, Council of Europe, Strasbourg, France, 7th edition, 2010.

[10] A. Sobczak, A. Jelińska, M. Leśniewska, A. Firlej, and I. Oszczapowicz, "Stability of epidoxorubicin in solid state," Journal of Pharmaceutical and Biomedical Analysis, vol. 54, no. 4, pp. 869872, 2010.

[11] J. Cielecka-Piontek, A. Jelińska, M. Zajac, M. Sobczak, A. Bartold, and I. Oszczapowicz, "A comparison of the stability of doxorubicin and daunorubicin in solid state," Journal of Pharmaceutical and Biomedical Analysis, vol. 50, no. 4, pp. 576579, 2009.

[12] A. Jelińska, J. Uszak, J. Cielecka-Piontek et al., "Stability of [(N-pyrrolidine)metylene]daunorubicin in aqueous solutions," Reaction Kinetics and Catalysis Letters, vol. 98, no. 1, pp. 69-75, 2009.

[13] P. Zalewski, M. Zając, A. Jelińska, J. Cielecka-Piontek, and I. Oszczapowicz, "Stability study of anticancer agent N[(Hexahydroazepin-1-yl)methyl] daunorubicin in aqueous solutions using HPLC method," Asian Journal of Chemistry, vol. 23, no. 2, pp. 835-838, 2011.

[14] J. Cielecka-Piontek, A. Jelińska, A. Dołhań et al., "Stability of new anticancer agents in intravenous solutions," Asian Journal of Chemistry, vol. 24, no. 2, pp. 769-772, 2012.

[15] A. Jelińska, M. Zaj,c, J. Cielecka-Piontek et al., "Validation of a stability indicating LC-UV method for [(N-morpholine) methylene]daunorubicin hydrochloride," Chromatographia, vol. 67, no. 1, pp. 107-111, 2008.

[16] L. Varshney and P. B. Dodke, "Radiation effect studies on anticancer drugs, cyclophosphamide and doxorubicin for radiation sterilization," Radiation Physics and Chemistry, vol. 71, no. 6, pp. 1103-1111, 2004.

[17] I. Morkunas and W. Bednarski, "Fusarium oxysporum-induced oxidative stress and antioxidative defenses of yellow lupine embryo axes with different sugar levels," Journal of Plant Physiology, vol. 165, no. 3, pp. 262-277, 2008.

[18] M. J. Frisch, G. W. Trucks, H. B. Schlegel et al., Gaussian 03, Revision D.01, Gaussian, Inc., Wallingford, Conn, USA, 2004.

[19] G. P. Jocobs, "The radation-sterilization of tetracycline hydrochloride," Journal of Pharmacy and Pharmacology, vol. 28, supplement 7, 1976. 

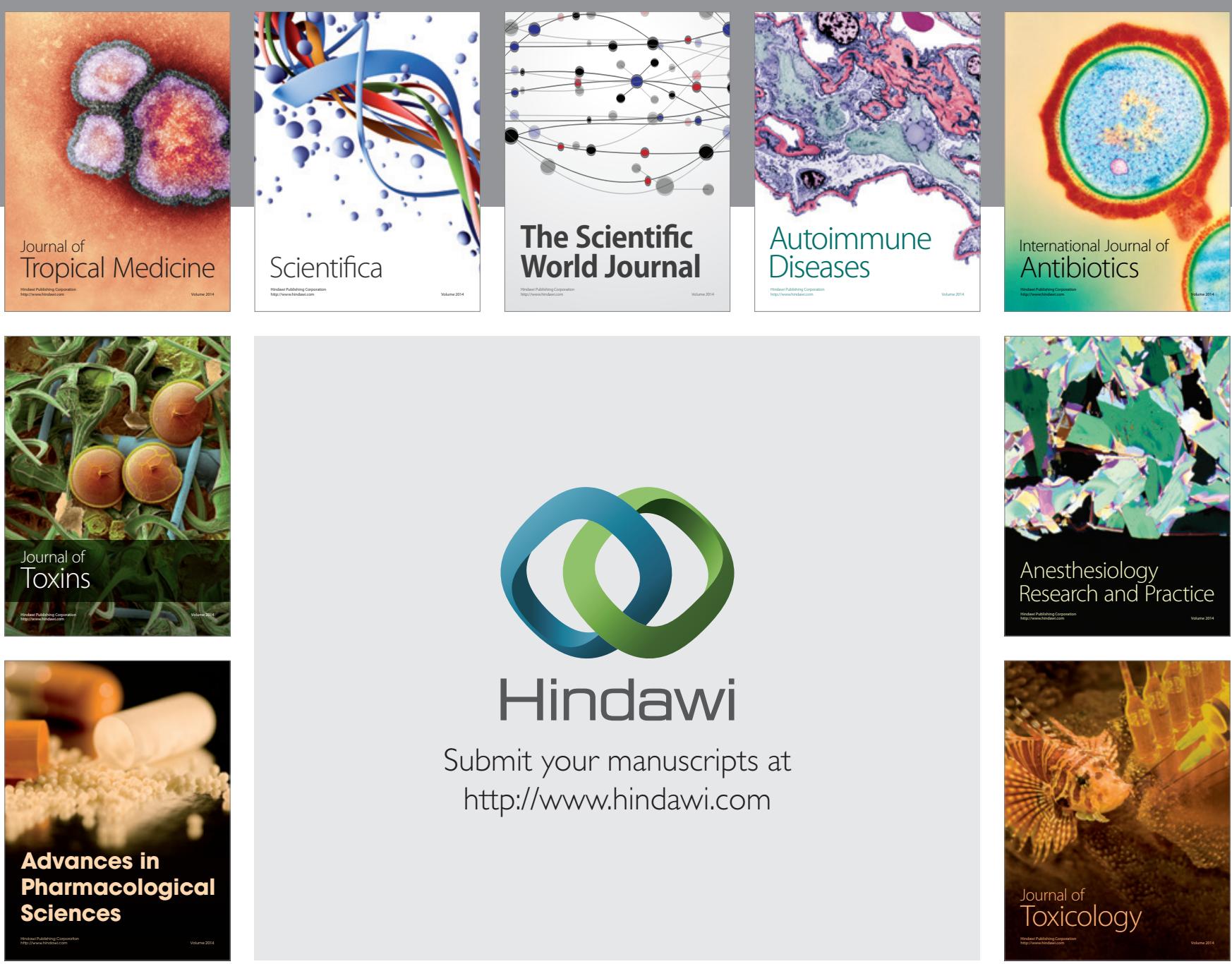

\section{Hindawi}

Submit your manuscripts at

http://www.hindawi.com
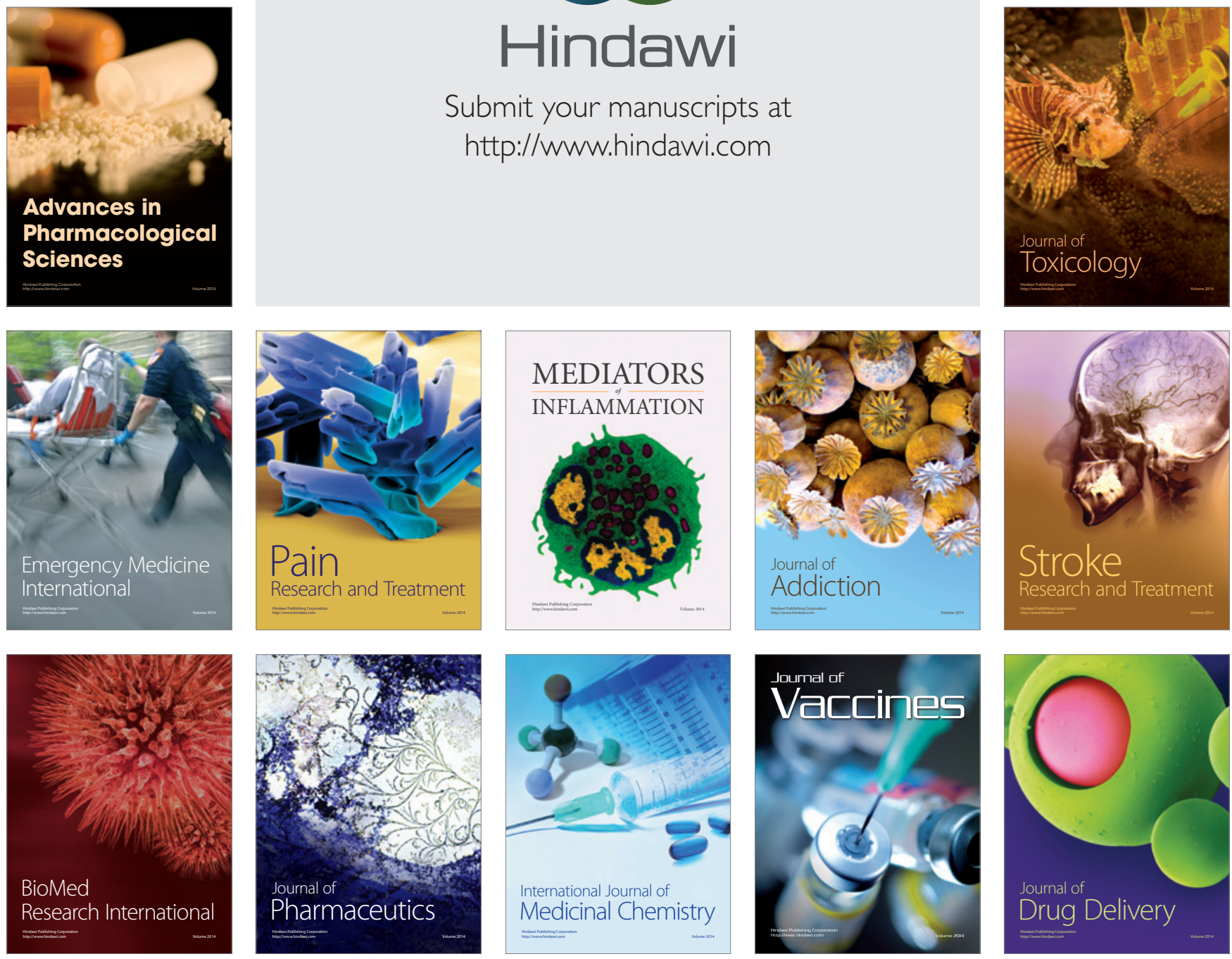